\title{
Sztuczna iluminacja miasta odpornego
}

\section{Artificial illumination of a resilient city}

\begin{abstract}
Streszczenie
Jednym z niedocenianych elementów struktury miejskiej, w szczególności struktury miasta odpornego (resilient city), jest sztuczna iluminacja przestrzeni publicznych. Zbyt często rozumie się ją jedynie jako aspekt funkcjonalny, inżynierski, podlegający czynnikom ekonomicznym. Jednakże sztuczna iluminacja rozumiana jako element czytelności kompozycji struktury przestrzeni miejskich, a co za tym idzie, przejaw rozwiązań estetycznych i kompozycyjnych, winna podlegać świadomym zasadom projektowania, podobnie jak struktury urbanistyczne i architektoniczne.
\end{abstract}

Słowa kluczowe: sztuczna iluminacja, miasto odporne, projektowanie oświetlenia

\section{Abstract}

One of the underestimated elements of the urban structure, in particular the structure of a resilient city, is the artificial illumination of public spaces. Too often it is understood only as a functional, engineering aspect, subject to economic factors. However, artificial illumination understood as an element of the legibility of the composition of the structure of urban spaces, and thus a manifestation of aesthetic and compositional solutions, should be subject to conscious design principles, as well as urban and architectural structures.

Keywords: artificial illumination, resilient city, light design 


\section{MIASTO ODPORNE A MATERIA SZTUCZNEJ ILUMINACJI}

„Miasto odporne" stosunkowo niedawno zostało wprowadzone jako pojęcie towarzyszące badaniom nad miastami. Odnosi się ono do wszystkich złożonych relacji struktury miasta (Bilska, 2016). Według OECD (b.r.) miasta odporne, to „miasta, które mają zdolność wchłaniania, odbudowy i przygotowania się na przyszłe wstrząsy (gospodarcze, środowiskowe, społeczne i instytucjonalne). Odporne miasta promują zrównoważony rozwój, dobrobyt i wzrost sprzyjający włączeniu społecznemu". Kluczowe w tym ujęciu jest określenie podstawowych obszarów analizy odporności miasta, czyli uwarunkowań gospodarczych, środowiskowych, społecznych i instytucjonalnych. W przyjętej metodzie brać należy pod uwagę wszystkie wymienione relacje w ujęciu bardzo szerokim, związanym nie tylko z tkanką analizowanego obszaru miejskiego, ale także w relacjach regionalnych czy wręcz ogólnoświatowych. Miasto odporne traktowane jest zatem jako integralna część systemu „naczyń połączonych”, w którym każdy fragment, niezależnie jak analizowanej struktury, ma wpływ na szeroko pojęte otoczenie ponad regionalne, a w efekcie ogólnoświatowe.

Jednym z elementów struktury miasta XXI wieku jest sztuczna iluminacja przestrzeni publicznych, zarówno jako iluminacja obiektów architektonicznych, jak i przestrzeni ulic, placów i parków (Hajdamowicz, 2007). Wydaje się, że pod kilkoma względami jest to element niedoceniany czy wręcz mylnie interpretowany. Szczególnie w Polsce sztuczna iluminacja jest głównie rozpatrywana pod względem ekonomicznym, funkcjonalnym czy ostatnio także ekologicznym. W krajach rozwiniętych, gdzie oświetlenie przestrzeni publicznych stanowi także element spójności tkanki miejskiej oraz jest aspektem estetycznym wynikającym z uwarunkowań społecznych i kulturowych, projektowanie sztucznego oświetlenia stanowi integralny czynnik miasta zrównoważonego i odpornego. Wedle zasady kształtowania miast przygotowanych na najróżniejsze kataklizmy naturalne, ekonomiczne czy społeczne, sztuczne oświetlenie nie jest li tylko funkcją, a wynikiem przemyślanych, wieloaspektowych, wielobranżowych działań, zintegrowanych w spójną formę.

Ostatnie miesiące, czyli czas pandemii koronawirusa, uwidoczniły zalety miast, w których wdrożono zasady miasta odpornego, w tym elementy sztucznej iluminacji przestrzeni publicznych, które podnosząc komfort i poczucie bezpieczeństwa, równocześnie stanowią przykład przewidywania zmienności uwarunkowań użytkowania środowiska miejskiego. Realizacja tak przyjętych uwarunkowań w miastach odpornych odbywa się poprzez proces, którego podstawą jest edukacja, zarówno społeczna, jak i branżowa, w zakresie projektowania sztucznej iluminacji. To także świadomość konieczności wdrażania i wykorzystywania najnowszych rozwiązań technologicznych, sprzyjających przewidywaniu zagrożeń, jakie niesie współczesność.

Z drugiej zaś strony ostatni rok odsłonił wszystkie wady zaniechań i podejmowania niewłaściwych lub nieprawidłowych działań w tym zakresie. Szczególnie w miastach, które wciąż są dalekie od spełnienia wymagań stawianych miastom odpornym. Doskonałym przykładem są tu przypadki polskich miast, jak choćby Kraków, gdzie ze względów ekonomicznych iluminacja przestrzeni publicznych została na pewien czas wyłączona (il. 1, 2). 
Wydarzenia te stanowią naoczny przykład niewdrożenia odpowiednich rozwiązań inżynierskich, braku działań związanych z kompleksowym opracowaniem spójnej idei oświetlenia miasta, dostosowanych do możliwych zmiennych warunków zastosowania. Oczywiście, pandemia jest drastycznym przykładem zagrożeń, jakich można się spodziewać we współczesnym świecie. Niemniej jednak właśnie takie wydarzenia najmocniej uwidaczniają wszelkie problemy w strukturze miast, a jednocześnie pokazują, jakie kroki należy podjąć, by można było je rozwiązać, wdrażając jednocześnie idee miasta odpornego.

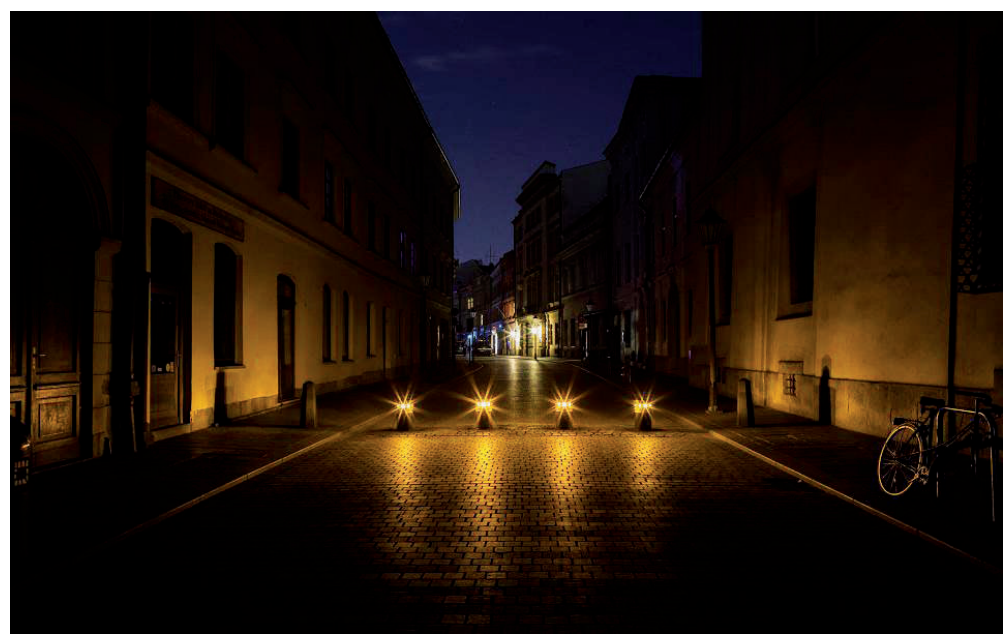

II. 1. Kraków bez oświetlenia, ul. Stolarska. Fot. Jakub Włodek, Agencja Gazeta

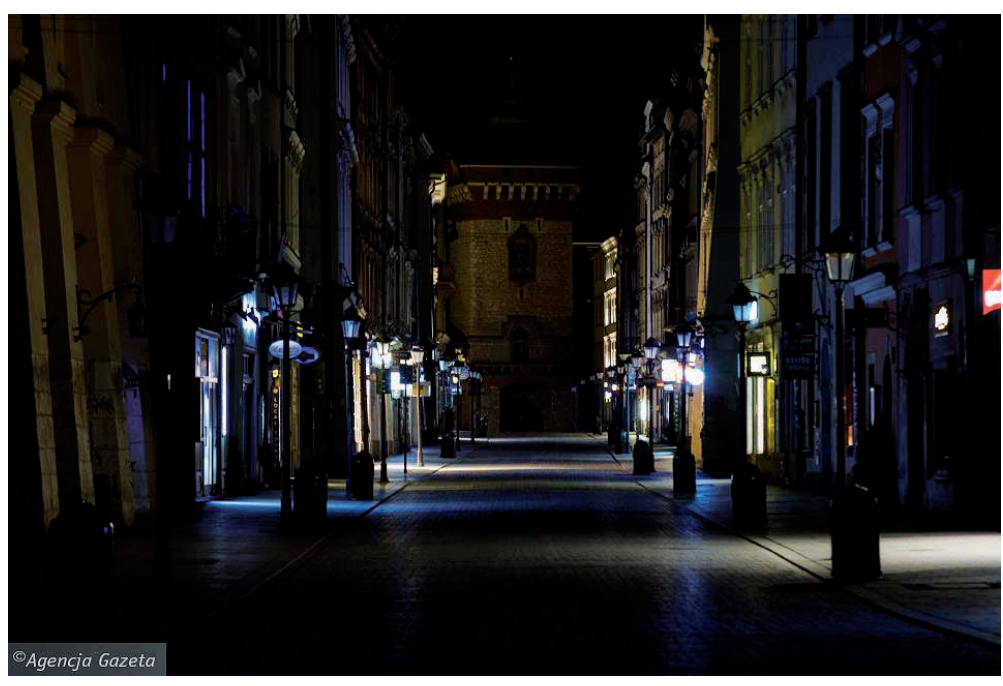

II. 2. Kraków bez oświetlenia, ul. Floriańska. Fot. Jakub Włodek, Agencja Gazeta 
Powstaje zatem pytanie, jak projektować współczesną iluminację w kontekście urbanistycznym? Jakich narzędzi używać, jakie stosować metody, aby spełniała ona wymagania stawiane miastom odpornym? I chyba najważniejsza z punktu widzenia odbiorcy i użytkownika przestrzeni miejskich kwestia - jak zachować względy estetyczne, aby działanie światłem było piękne?

\section{ASPEKTY INŻYNIERSKIE}

Reguły miasta odpornego związane są we wszystkich swoich uwarunkowaniach ze sposobem, w jaki należy projektować sztuczną iluminację. Każdy z tych podstawowych czterech obszarów analizy (ww. uwarunkowania) ma swoje odniesienie do poruszanej problematyki, co znacząco podnosi jej ważność. Należy zatem spojrzeć na nią zarówno w kontekście możliwych rozwiązań czysto inżynierskich, jak i plastycznych i kompozycyjnych, co wbrew pozorom nie zawsze jest spojrzeniem tożsamym w odniesieniu do poszczególnych reguł miasta odpornego.

\subsection{UWARUNKOWANIA ŚRODOWISKOWE}

Odporność w rozumieniu projektowania sztucznej iluminacji to przede wszystkim zastosowanie nowoczesnych i zaawansowanych technologicznie rozwiązań z zakresu techniki świetlnej. Z jednej strony głównym czynnikiem jest stosowanie jak najbardziej energooszczędnych, ale wydajnych źródeł światła, w tym przypadku zaawansowanej technologii LED (choć w przyszłości możliwe jest wdrożenie innych technologii). Takie działania niosą od razu wymierne korzyści pod względem zużycia prądu, a zatem w efektywny sposób przyczyniają się do zmniejszenia emisji $\mathrm{CO}_{2}$. I o ile takie działania na szeroką skalę są stosowane w większości miast polskich, o tyle następuje tu jedynie wymiana samych opraw ze starych, nieefektywnych wyładowczych. Zazwyczaj nie wdraża się na szeroką skalę towarzyszących im rozwiązań technologicznych, umożliwiających inteligentne sterowanie. Sterowanie to pozwoliłoby na przykład na regulację natężenia oświetlenia z uwagi między innymi na zmienną intensywność ruchu, porę nocy czy warunki atmosferyczne (Kołakowski, 2017). Możliwe jest sterowanie całymi zespołami opraw lub pojedynczymi oprawami oświetleniowymi. Same zaś źródła światła w oprawach mogą być dowolnie ustawione, tak aby zapewniać zoptymalizowane generowanie wiązki światła na wybrany i ściśle określony fragment powierzchni, którą należy oświetlić. Systemy sterujące oczywiście nie dotyczą jedynie oświetlenia ulicznego, drogowego. Są przystosowane do dowolnej infrastruktury oświetleniowej, także tej związanej z iluminacją obiektów. Wykorzystanie tego typu systemów pozwala na jeszcze większe ograniczenie zużycia energii elektrycznej, a zatem zminimalizowanie bezpośredniego wpływu na środowisko. 


\subsection{ASPEKTY SPOŁECZNE}

Przestrzeń miejska oświetlona światłem sztucznym to także ważny z punktu widzenia społecznego aspekt tkanki miasta odpornego. Sztuczne oświetlenie, szeroko pojmowane jako przejaw zapewnienia użytkownikom miasta możliwości egzystencji po zapadnięciu mroku, daje przede wszystkim poczucie bezpieczeństwa. Jest zatem bardzo istotnym elementem struktury inżynierskiej miasta. Przestrzeń miejska oświetlona zachęca do przebywania w niej, nie tylko uwypuklając jej funkcjonalność, ale także zachęcając do gromadzenia się, spotykania. Przyjęło się mówić, że miasto, które nie śpi, to także miasto bezpieczne. Miasto, w którym społeczność nie tylko musi, ale chce wykorzystywać swoją przestrzeń także nocą, w poczuciu bezpieczeństwa i komfortu. Niemniej jednak potrzeby zgromadzeń, spotkań różnych grup użytkowników, nie podlegają schematom. Dlatego struktura oświetleniowa miasta, powinna być realizowana z uwzględnieniem zmienność rytmu życia jego użytkowników. Ten rytm to uwarunkowania zarówno klimatyczne (zmiany pogody, pór roku), możliwości wykorzystania czasu wolnego (święta, imprezy okolicznościowe), jak i po prostu różnice wynikające z pory nocy. To, co w aspekcie społecznym - być może najważniejszym, bo bez niego w ogóle nie trzeba by oświetlać przestrzeni miejskiej - jest najbardziej istotne dla uwarunkowania społecznego według przyjętych metod dla miasta odpornego, to analizowanie i przewidywanie sposobu wykorzystania sztucznej iluminacji do potrzeb w danym momencie. Zatem następuje tu powiązanie aspektów inżynierskich i ich umiejętnego wykorzystania w związku z oczekiwaniami społecznymi.

\subsection{ROZWIAZZANIA DLA ZAGROŻEŃ EKONOMICZNYCH}

Miasto jako jednostka, ponoszące obciążenia ekonomiczne na jak najmniejszym poziomie, to miasto odpowiedzialne, zrównoważone i dbające o mieszkańców. Pamiętać należy, że miasta nie posiadają „swoich” pieniędzy, gdyż są to de facto finanse pochodzące z podatków ich mieszkańców. Tak więc rozsądne i zrównoważone podejście w aspekcie ekonomicznym do iluminacji przestrzeni miejskiej powinno być celem głównym dla każdego miasta aspirującego do miana „odpornego".

Nie chodzi tu jedynie o możliwości wykorzystywania technologii LED w celu ograniczenia zużycia energii elektrycznej, choć jest to najprostszy przykład wykazania zależności ekonomicznych do realizacji projektowania sztucznej iluminacji miast. Innym ważnym aspektem jest wpływ oświetlenia nocnego na turystykę, która niejednokrotnie stanowi istotny element gospodarki ośrodków miejskich. Należy przewidywać oddziaływanie turystyki kulturowej, krajobrazowej czy eventowej lub jakiejkolwiek innej na mechanizmy gospodarcze miasta, a zatem także na możliwości kreowania światłem sztucznym atrakcyjności jego przestrzeni, ale także na zmiany możliwości wykorzystania sztucznej iluminacji, jakie może wywoływać, np. gwałtowny napływ (z uwagi na wielkie koncerty czy rozgrywki sportowe) 
lub odpływ (z uwagi na zagrożenia terrorystyczne czy pandemie) turystów. Tak więc wprowadzanie nowoczesnych systemów kompleksowego sterowania sztuczną iluminacją wydaje się nieodzownym elementem wspomagającym przewidywanie i unikanie mogących nastąpić zagrożeń ekonomicznych, podobnie jak konieczność przyjęcia takich rozwiązań projektowych, które będą promowały ograniczenie użycia oświetlenia przy jednoczesnym zapewnieniu spełnienia wszelkich norm prawnych.

\subsection{SPOJRZENIE NA UWARUNKOWANIA INSTYTUCJONALNE}

Nawarstwia się tu wiele różnych problemów, od kwestii ekonomicznych, własnościowych, formalno-prawnych czy nawet kompozycyjnych i stylistycznych. Rozwiązaniem jest tworzenie miejscowych planów oświetleniowych regulujących wszelkie podstawowe zasady tworzenia sztucznej iluminacji. Zarządzanie iluminacją, tworzenie spójnego obrazu miasta nocą, a więc tworzenie miejscowych planów oświetleniowych.

Samo tworzenie miejscowych planów oświetleniowych jest procesem długotrwałym, zatem nieuniknione wydaje się, że w miastach będących w budowie powstawać będą iluminacje przestrzeni miejskich punktowo, uzależnione od ograniczonych możliwości ich skomponowania. Zatem kluczem do celu jest wdrożenie odpowiedniego systemu dydaktycznego, nastawionego na wykształcenie odpowiednich fachowców, posiadających wiedzę z zakresu projektowania sztucznego oświetlenia, wykorzystania zasobów technicznych (a zatem stawiania przedstawicieli producentów w podmiotowej roli), planowania urbanistycznego, architektonicznego czy elementów socjologii.

Największym zagrożeniem są tu zmiany w strukturach instytucjonalnych, podejmowanie przez przedstawicieli władz decyzji o wprowadzaniu gwałtownych zmian legislacyjnych. Z drugiej strony stabilność instytucjonalna w połączeniu z wykształconą kadrą projektową dają możliwość skutecznego i stopniowego wprowadzania zmian, stanowiąc jednocześnie element „domykający” dla pozostałych uwarunkowań miasta odpornego. Instytucje samorządowe powinny pełnić zatem rolę przewodnią w promowaniu nowoczesnych rozwiązań sztucznej iluminacji przestrzeni miast.

\section{PIĘKNO W PROCESIE KSZTAŁTOWANIA MIASTA ŚWIATŁEM}

Czy we współczesnym mieście, niezależnie od jego modelu, funkcjonowania i struktury, jest miejsce na iluminację przestrzeni publicznych, która będzie nie tylko funkcjonalna i spełniająca założenia podporządkowane ideom miasta odpornego, ale także będzie podkreślać piękno, sama upiększając przestrzeń miejską? Odpowiedź na to pytanie wydaje się być oczywista. Każdy z nas obserwuje pięknie oświetlone przestrzenie, iluminacje obiektów i oświetlenie dynamiczne przestrzeni w formie festiwali światła. Można powiedzieć, 
że sztuczna iluminacja ma wpływ na ludzkie emocje, dzięki niej stajemy się częścią przestrzeni miejskiej. Jednakże bardzo często nasze postrzeganie iluminowanej przestrzeni ogranicza się do pojedynczego obiektu, zamkniętej skomponowanej przestrzeni czy zespołu obiektów. Jest to w sposób oczywisty związane ze skalą miasta w odniesieniu do człowieka, niemniej jednak efekt „prowadzenia światłem” obserwatora, łączenie i przenikanie przestrzeni światłem, ich wzajemne komponowanie, jest elementem ograniczonym zazwyczaj do, rzec by można, ścieżki edukacyjnej, trasy turystycznej czy po prostu głównych ciągów komunikacyjnych. Zatem nieświadomie stajemy się produktem konsumenckim, z punktu widzenia tak wydawałoby się trywialnego, jak możliwość przeżywania piękna sztucznej iluminacji przestrzeni publicznych. Problemem, z którym się w tej materii stykamy, to traktowanie producentów oświetlenia jak projektantów (Nanni, 2011), a należy tu wyraźnie oddzielić działania marketingowe od projektowania. Wydaje się, że przecież efekt końcowy w postaci sztucznej iluminacji otrzymujemy ten sam, jednak jest to jedynie złudzenie. Niesprawiedliwe byłoby twierdzenie, że wszystkie projekty są wykonywane bez udziału projektantów oświetlenia czy świadomych wartości właściwej iluminacji architektów, niemniej problemem jest działanie jednostkowe, punktowe, podejmowane w oderwaniu od kontekstu ogółu przestrzeni miejskiej. W konsekwencji mamy do czynienia z brakiem spójności realizowanych koncepcji projektów oświetleniowych w przestrzeniach stanowiących spójną całość.

Współczesne światowe tendencje w projektowaniu sztucznej iluminacji przestrzeni miejskich tworzą skomplikowaną nić powiązań pod względem zakresu podjętych działań analitycznych związanych z wieloma aspektami kulturowymi, społecznymi oraz oczywiście urbanistycznymi, architektonicznymi, także z zakresu historii architektury i urbanistyki oraz samej techniki świetlnej. Z działań tych wyłania się obraz iluminacji miasta łączącego wszelkie możliwe aspekty w spójną całość. Oczywiście instalacja, dystrybucja i wykorzystanie zróżnicowanych typów oświetlenia to ogromne wyzwanie, tak aby możliwym było stworzenie indywidualnej opowieści miasta o jego historii, strukturze (Van Santen, 2006).

Jest to model, w którym oświetlenie ulic, placów, głównych punktów węzłowych stanowi równie ważny element jak iluminacja pomników, najważniejszych budowli miasta, ale także oświetlenie wewnętrzne biur, witryn sklepowych czy klatek schodowych. Może się wydawać zaskakującym świadome wykorzystanie eksponowanych elementów wnętrz, czy raczej ich oświetlenia do programu iluminacji przestrzeni publicznych, co jest w sumie działaniem logicznym, biorąc pod uwagę same idee architektury do kreowania formy budynków, eksponowania elementów wnętrz na widok publiczny. Podany na początku niniejszego artykułu przykład krakowskich trudności ekonomicznych z okresu pandemii i konieczności wyłączania iluminacji przestrzeni miejskich pokazuje, że nawet przy podjęciu takich działań przestrzeń miejska wciąż pozostaje w jakimś zakresie oświetlona, właśnie poprzez wydobywające się z wnętrz światła witryn sklepowych czy szyldów reklamowych. Oczywiście nie można założyć, że tego typu iluminacja jest równa iluminacji publicznych przestrzeni. Może ona 
stanowić jedynie dodatek, dyskretne obramowanie, uzupełnienie. Niemniej jednak musi być brana pod uwagę jako ważny, istniejący w przestrzeni nocnej panoramy miasta element.

We współczesnych tendencjach iluminacji miasta istotne stało się nieprześwietlanie żadnej z przestrzeni publicznych. Człowiek potrzebuje określonej ilości światła do odnajdywania się w otaczającej go przestrzeni, niemniej jednak pora nocna wymaga, aby to oświetlenie było z nią kojarzone. Niewłaściwym jest stosowanie dawnych technik iluminacyjnych, polegających na „zalewaniu” światłem otoczenia. Rozumienie stosowania adekwatnej ilości światła polega także na umiejętnym wykorzystaniu czynnika odbicia światła od powierzchni, na jaką pada, w celu jego dystrybucji w otoczeniu (il. 3). Umiejętne zastosowanie tego efektu daje poczucie miękko otaczającego nas światła, jednocześnie nie zaburzając percepcji przestrzeni.

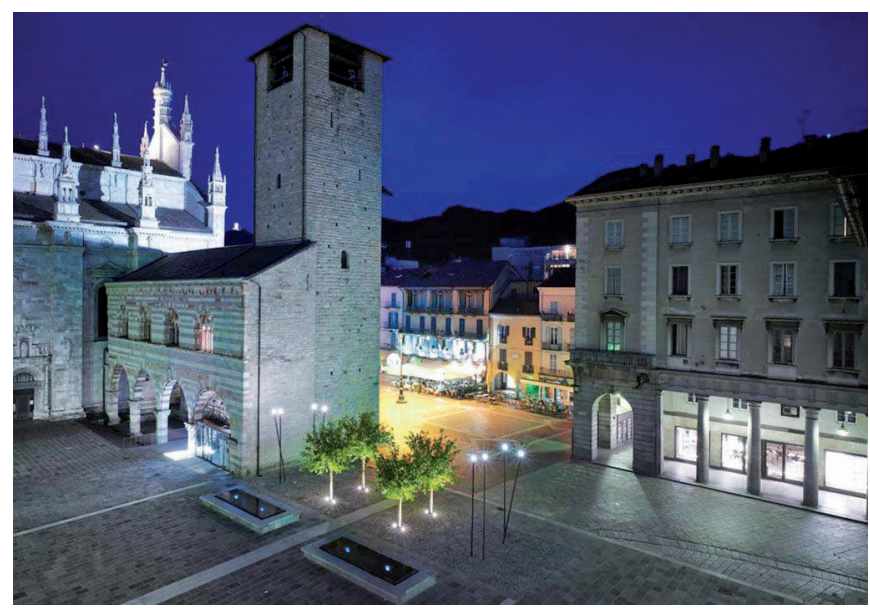

II. 3. Como, Włochy, Piazza Grimoldi. Fot. UpO Viabizzuno

Pojawia się tu też ważny aspekt samego projektowania iluminacji, czy może raczej czynnika nieodzownie jej towarzyszącego, czyli cienia (il. 4, 5). Jego kreacja staje się dominującym elementem, gdyż dzięki niemu lepiej rozumiemy działanie światła. Cień daje nam większe zrozumienie trójwymiarowości, jednocześnie podkreślając elementy ważniejsze, bardziej charakterystyczne, ukrywając to, co jest mniej istotne. W przestrzeni publicznej cień nie jest zupełną ciemnością. Stanowi tło lub nieistotne przedpole dla tego, co najistotniejsze, nie pozbawiając nas jednocześnie poczucia bezpieczeństwa i możliwości prawidłowej orientacji.

Przy zastosowaniu odpowiednich rozwiązań inżynierskich, umożliwiających spełnienie założeń miasta odpornego w zakresie iluminacji nocnej, wykorzystanie wiedzy z zakresu techniki świetlnej oraz produktowej umożliwia projektowanie jej w sposób zróżnicowany, a zatem stosowanie najróżniejszych typów opraw, ich lokalizacji, wielkości i uzyskanego dzięki temu efektowi. Nie zawsze oprawa powinna być „latarnią” na słupie (il. 6, 7). 


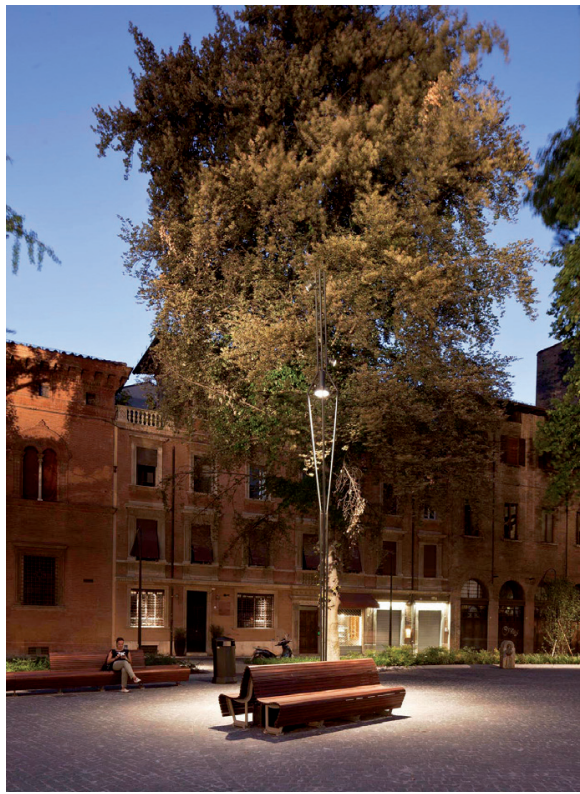

II. 4. Bologna, Włochy, Piazza Minghetti. Fot. UpO Viabizzuno

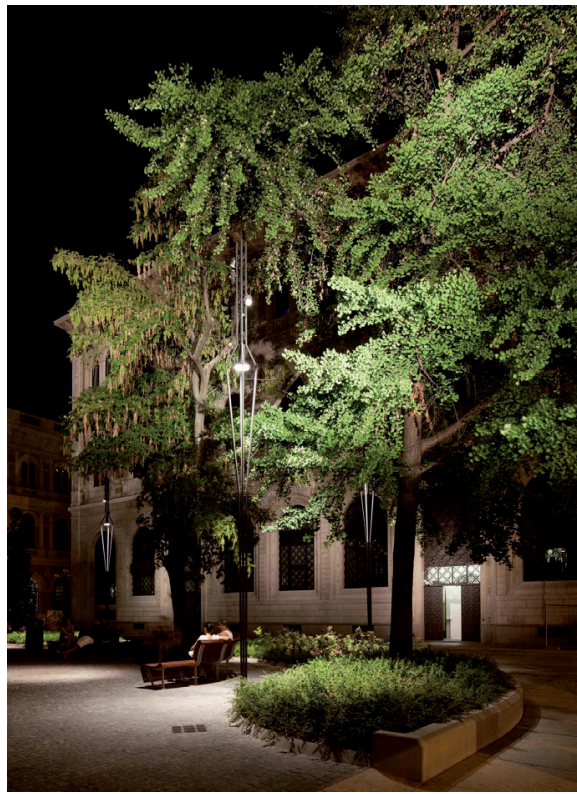

II. 5. Bologna, Włochy, Piazza del Francia. Fot. UpO Viabizzuno

II. 6. Paryż, Francja, Jardins de l'Arche.

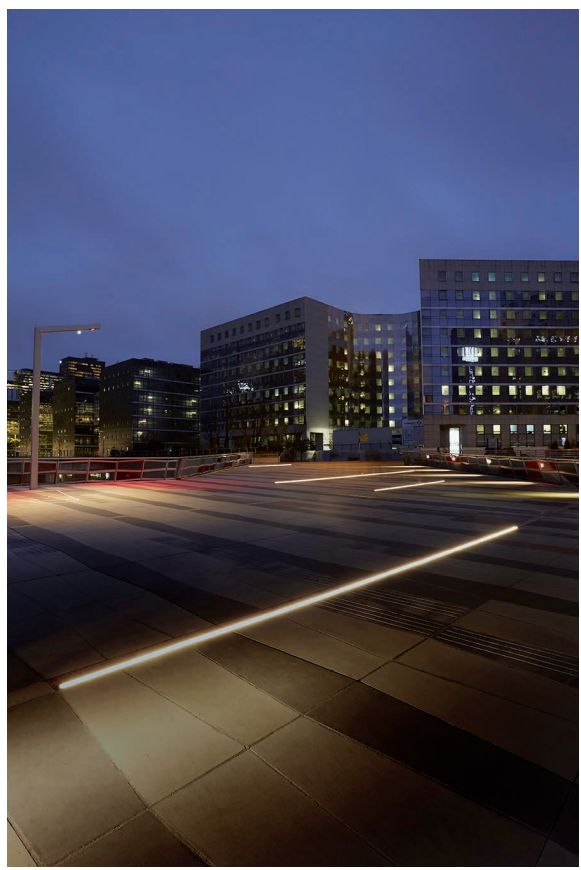




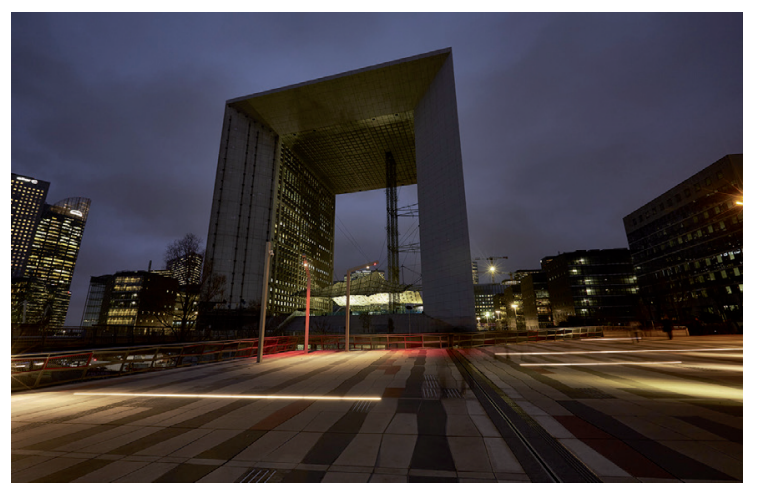

II. 7. Paryż, Francja, Jardins de l'Arche.

Fot. Luce\&Light

Dzięki tym rozwiązaniom można świadomie wydzielać, łączyć lub przenikać kompozycyjnie przestrzeń miejską. Podkreślać sposób jej użytkowania jako całość lub jako fragment. Właściwie przyjęte rozwiązania projektowe sprawić mogą, iż przestrzeń będzie „tętnić” światłem.

\section{PROCES KSZTAtTOWANIA MIASTA ŚWIATŁEM}

Cel oświetlenia przestrzeni, jej sposób użytkowania, funkcjonalność i kontekst to elementy podlegające analizie mającej zagwarantować komplementarność iluminacji przestrzeni publicznych, zapewniających ciągłość funkcjonalną i kompozycyjną, podkreśloną przez jej zmienność, nierównomierność, podobnie jak całej przestrzeni urbanistycznej. Niezależnie od przyjętej klasyfikacji zasad projektowania oświetlenia przestrzeni miejskich, takich jak iluminacja spektakularnych przedsięwzięć architektonicznych i urbanistycznych, rewitalizacja przestrzeni miejskich światłem, spójne strategie oświetleniowe miast (master plan oświetleniowy) czy wreszcie czasowe atrakcje okolicznościowe i festiwale światła (Martyniuk-Pęczak, 2014), ich realizacja we współczesnym modelu miasta odpornego stanowi jedno z podstawowych wyzwań. Biorąc pod uwagę zależności zarówno ekonomiczne, społeczne, kulturowe, jak i estetyczne w kontekście przyszłości rozwoju miast odpornych, należy dążyć do świadomego kreowania przestrzeni światłem, co przedstawiają wykształceni projektanci oświetlenia, architekci i urbaniści. Proces ten odbywać się powinien w ścisłej współpracy pomiędzy wymienionymi specjalistami, instytucjami samorządowymi i lokalnymi społecznościami.

\section{PODSUMOWANIE}

Wydawać by się mogło, iż realizacja koncepcji miasta odpornego w zakresie stosowania odpowiednich rozwiązań inżynierskich jest końcową receptą na sukces programu oświetlenia miasta. Stosowanie tego typu rozwiązań jest najczęściej rozumiane jako element 
odrębny w stosunku do kompleksowego rozumienia tkanki urbanistycznej, traktowany jako rozwiązanie jedynie funkcjonalne, oparte na wytycznych zawartych w określonych ramach formalno-prawnych i normatywnych, najczęściej odrębnie rozwiązywane w stosunku do przestrzeni o charakterze głównych punktów identyfikacji miasta.

Koncepcje miasta odpornego są realizowane współcześnie w zakresie wszelkich aspektów środowiskowych, społecznych, ekonomicznych i instytucjonalnych, lecz nie zawsze realizowane są w aspekcie estetycznym, tak aby wykorzystać potencjał miasta odpornego do bycia pięknym. Oczywiście, piękno jest niewymierne i różnie rozumiane, ale właśnie tym elementem zajmować się powinna wykwalifikowana grupa projektantów, odrębnych specjalistów, odpowiadająca za integrację wszelkich elementów idei miasta odpornego. W światowych tendencjach związanych z projektowaniem oświetlenia jako odrębnej materii projektowej pojawia się tendencja do włączania wszelkich systemów oświetleniowych w spójną tkankę kompozycyjną, świadomie projektowaną.

Miasto odporne w kontekście sztucznej iluminacji przestrzeni publicznych to świadome realizowanie programu właściwej dystrybucji oświetlenia, w sposób zrównoważony, ekologiczny i ekonomiczny, z możliwością jego adaptacji do podstawowych czynników klimatycznych, ale także rytmu jego życia, jego zmiennych potrzeb oraz możliwych do przewidzenia niespodziewanych zagrożeń. Miasto odporne to miasto świadomie projektowane w sposób użyteczny i bezpieczny, ale przede wszystkim piękny. Po zmroku zaś piękno powinno być nadal widoczne.

\section{BIBLIOGRAFIA}

OECD (b.r.). Resilient cities main page. Pobrane z https://www.oecd.org/cfe/regionaldevelopment/resilient-cities.htm (dostęp: 16.03.2021).

Bilska, A. (2016). Proces budowy miasta odpornego na przykładzie Rotterdamu. Rozwój regionalny i polityka regionalna, 34, 59-78.

Hajdamowicz, R. (2007). Iluminacja środowiska zamieszkania. Czasopismo Techniczne, 2A, 24-28. Kołakowski, M. (2017). Inteligentne systemy zarzq̨dzania ulicznym oświetleniem LED. Pobrane z:

http://lighting.pl/oswietlenie-profesjonalne/drogi-i-ulice (dostęp: 15.03.2021).

Martyniuk-Pęczak, J. (2014). Światła miasta. Wrocław: Wydawnictwo MARINA.

Nanni, M. (2011). Emotion and concentration, AND, LUCE>DESIN, 20, 136-143

Van Santen, Ch. (2006). Light Zone City, Light Planning in the Urban Context. Basel: Birkhauser. 
